\title{
Distribution and prevalence of coral diseases in the Veracruz Reef System, Southern Gulf of Mexico
}

\author{
J. P. Carricart-Ganivet ${ }^{1,2, *}$, A. U. Beltrán-Torres ${ }^{2}$, G. Horta-Puga ${ }^{3}$ \\ ${ }^{1}$ Unidad Académica de Sistemas Arrecifales, Instituto de Ciencias del Mar y Limnología, \\ Universidad Nacional Autónoma de México, Apdo. Postal 1152, Cancún, 77500 Quintana Roo, México \\ ${ }^{2}$ El Colegio de la Frontera Sur, Unidad Chetumal, Av. Centenario km 5.5, Apdo. Postal 424, Chetumal, 77000 Quintana Roo, \\ México \\ ${ }^{3}$ Lab. Biogeoquímica, UBIPRO, Facultad de Estudios Superiores Iztacala, Universidad Nacional Autónoma de México, \\ Av. de los Barrios 1, Los Reyes Iztacala, Tlanepantla, México 54910, México
}

\begin{abstract}
Ten reefs of the Veracruz Reef System (VRS) were surveyed to evaluate the distribution and prevalence of diseases that affect stony corals. Total disease prevalence on corals in the VRS was $4.8 \%$. Seven diseases affecting 6 coral genera (4 of which are the most abundant) were observed in $85.2 \%$ of the evaluated sites. As observed in other reefs of the Caribbean, dark spots disease had the highest prevalence $(2.9 \%)$ and widest distribution. The incidence of disease showed a patchy distribution, with prevalence being significantly higher on the reef flats than on the windward and leeward sides.
\end{abstract}

KEY WORDS: Coral disease $\cdot$ Stony corals $\cdot$ Veracruz Reef System $\cdot$ Mexico Resale or republication not permitted without written consent of the publisher

\section{INTRODUCTION}

Infectious diseases affecting major reef-building coral species have been identified as the most important factor contributing to the loss of live coral cover and population declines in corals, resulting in the deterioration of coral reefs. Consequently, they are an emerging threat to West Atlantic coral reefs (Harvell et al. 2004, Ward \& Lafferty 2004, Weil 2004, Willis et al. 2004, Bruckner \& Bruckner 2006, Weil et al. 2006, Ballantine et al. 2008). Diseases affect reef ecosystems by causing major shifts in community structure. For example, the shift from acroporid- to agaricid-dominated reefs in Belize was probably caused by disease-induced mortality of acroporid corals (Aronson et al. 2002).

The growing incidence of coral diseases, as well as increased disease prevalence and rate of spread on coral colonies, is attributed to increases in pathogen prevalence and virulence associated with global warming and low water quality (Bruckner \& Bruckner 1997a, Kim \& Harvell 2002, Bruno et al. 2003, Cervino et al. 2004, Voss \& Richardson 2006, Weil et al. 2006, Baker et al. 2007, Harvell et al. 2007, Muller \& van
Woesik 2009). For example, black band disease, white plague and dark spots disease have been associated with warm $\left(>30^{\circ} \mathrm{C}\right)$ water temperature (Kuta \& Richardson 2002, Brandt \& McManus 2009). Some experimental nutrient enrichment around Montastraea annularis increased the rate of spread yellow band disease (Bruno et al. 2003).

The Veracruz Reef System (VRS) is located in the Southern Gulf of Mexico, off Veracruz City, the most important and biggest cargo port in Mexico (19 $03^{\prime}$ to $19^{\circ} 12^{\prime} \mathrm{N}_{i} 95^{\circ} 56^{\prime}$ to $96^{\circ} 04^{\prime} \mathrm{W}$; Fig. 1 ). The VRS is divided into 2 groups by the influence of the fluvial plume of the Jamapa River: the North and the South groups. In the VRS, annual mean sea surface temperature (SST) has increased around $0.3^{\circ} \mathrm{C}$ during the last $20 \mathrm{yr}$, which is equivalent to $1.9^{\circ} \mathrm{C}$ per century (SST data were obtained from the Hadley Centre Sea Ice and SST data set; see Rayner et al. 2003). Although $20 \mathrm{yr}$ is a period too brief to exclude the possibility of decadal weather variations, the observed trend is consistent with the predictions of most climatic change models (e.g. IPCC 2007).

Anthropogenic impacts in the VRS stem from major port activities and human population growth. Oil spills, 


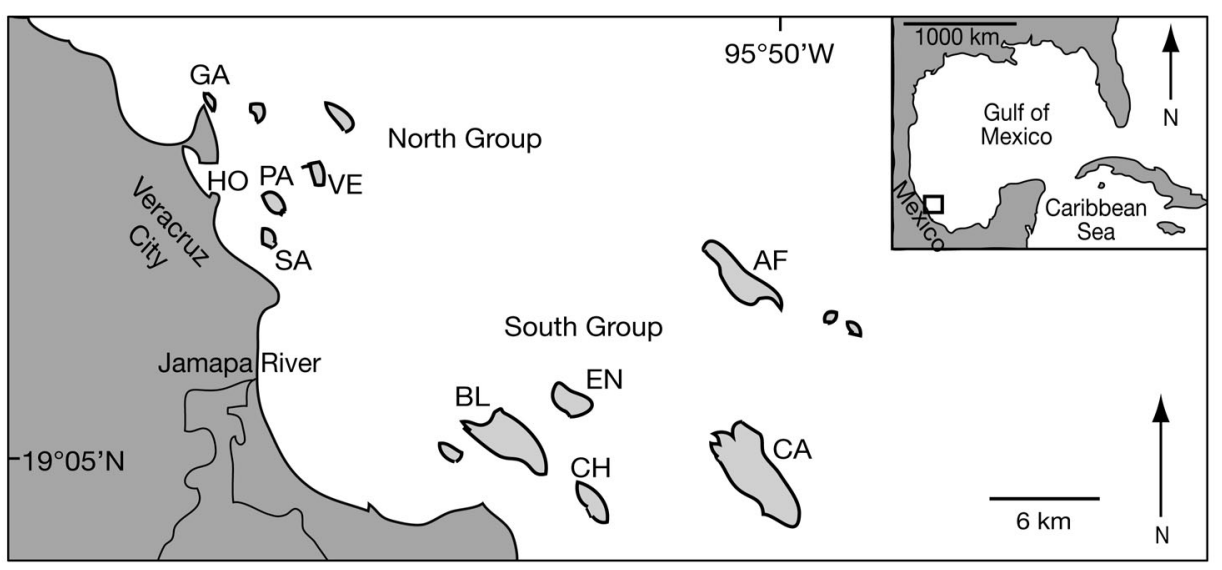

Fig. 1. Location of the Veracruz Reef System and reefs surveyed. North group: Galleguilla (GA), Isla Verde (VE), Hornos (HO), Pájaros (PA), and Isla Sacrificios (SA). South group: Anegada de Afuera (AF), Isla de Enmedio (EN), Blanca (BL), Cabezo (CA) and Chopas $(\mathrm{CH})$

discharges of other chemical pollutants, overfishing, unrestricted recreational diving, ship groundings, sewage effluents, dredging, and boat anchoring have led to polluted, turbid and highly nutrient-enriched waters in the VRS (Horta-Puga \& Carricart-Ganivet 1990, Tunnell 1992, Lang et al. 1998, Cruz-Piñón et al. 2003, Horta-Puga 2003, 2007). As a consequence, the entire VRS was decreed a marine protected area by the Mexican Government in 1992.

The aim of this study was to assess the prevalence and distribution of diseases on reef-building corals in the VRS in order to provide information for improved management of this important reef system.

\section{MATERIALS AND METHODS}

We surveyed 3988 colonies of stony corals, belonging to 16 genera (Table 1) and distributed in 480 line transects $(10 \mathrm{~m}$ apart), to evaluate the distribution and prevalence of diseases that affect these organisms in the VRS. Surveys were carried out in September 2006 and March, July, September, October, and November 2007 using the sampling protocol designed by the Atlantic and Gulf Rapid Reef Assessment Program (AGRRA methodology v. 4.0, www.agrra.org) with some minor modifications (we assessed all living corals that could be seen by the naked eye and that underlay the transect line). On each occasion, the same group of divers performed the surveys, and data were obtained from 10 reefs: 5 each from the North group and the South group (Fig. 1). At each reef - with the exception of Hornos, Blanca and Chopas -3 zones were studied: the windward reef, the reef flat and the leeward reef (see Table 3). Hornos is fringing reef, i.e. without a leeward side, and in Blanca and Chopas environmental conditions did not allow sampling.
Table 1. Number of coral colonies per genus surveyed to evaluate diseases in the Veracruz Reef System. D = genus that presented diseases

\begin{tabular}{|lrc|}
\hline Coral genus & No. of colonies & Disease presence \\
\hline Acropora & 7 & \\
Agaricia & 88 & \\
Colpophyllia & 495 & $\mathrm{D}$ \\
Diploria & 424 & $\mathrm{D}$ \\
Leptoseris & 10 & \\
Madracis & 56 & \\
Manicina & 28 & \\
Millepora & 25 & $\mathrm{D}$ \\
Montastraea & 741 & \\
Mussa & 1 & \\
Mycetophyllia & 1 & $\mathrm{D}$ \\
Oculina & 71 & \\
Porites & 362 & $\mathrm{D}$ \\
Scolymia & 3 & $\mathrm{D}$ \\
Siderastrea & 1573 & \\
Stephanocoenia & 103 & \\
Total & 3988 & \\
\hline
\end{tabular}

Coral genera were identified following Humann (1998), and diseases were identified using US government issued disease identification cards obtained from the National Oceanic and Atmospheric Administration (NOAA) (Bruckner \& Bruckner 1998a,b,c,d) and published descriptions of each condition. Dark spots disease (DSD) was identified from the scattered occurrence of dark purple to gray or brown patches of discolored tissue, often circular in shape but also occurring in irregular shapes and patterns (GarzónFerreira et al. 2001). White plague (WPL) created a sharp line between receding tissue and the skeleton (Bruckner \& Bruckner 1997b, Richardson et al. 1998). Rapid tissue necrosis (RTN) was characterized by fast tissue degradation (peeling) and death of the colony 
(Luna et al. 2007). White pox disease (Wpox) caused necrotic patches, with necrosis at the boundary of the living coral tissue leaving behind a bare but otherwise undamaged skeleton (Rodríguez-Martínez et al. 2001). Hyperplasia (HPL) was observed as a coral growth anomaly followed by necrosis associated with algae (Work \& Rameyer 2005). Black band disease (BBD) was identified as a black mat several millimeters to centimeters wide on the surface of the coral tissue. Signs of yellow band disease (YBD) included irregularly shaped areas of lightened yellow tissue on the coral surface in early stage infections; later stages produced dead areas, sometimes filled with sediment or algae, surrounded by a band of yellow tissue (Cervino et al. 2001).

Disease prevalence was computed for the VRS (total prevalence) for each group, reef, reef zone, and genus as the percent of diseased colonies relative to the total colonies in each case (i.e. disease prevalance $=$ [no. of diseased colonies/no. of total colonies] $\times 100$ ). Data were analyzed at the community and genus levels. A nested Analysis of Variance (ANOVA) was computed as a function of Group, Reef and Zone to show which component made the highest contribution to disease prevalence. Differences between the North and South groups were analyzed using a $t$-test for independent samples, and between reefs, reef zones, and genera with 1-way ANOVAs, followed by Tukey's HSD tests.

\section{RESULTS}

The total disease prevalence on corals in the VRS was $4.8 \%$. The effect of Group, Reef and Zone on disease prevalence is presented in Fig. 2. Variance Components Analysis (Table 2) showed that Zone made the

Table 2. Variance Components Analysis of coral disease prevalence by Group, Reef and Zone surveyed in the Veracruz Reef System. Each factor after the first is nested in the one above. Contribution indicates the percentage of disease prevalence explained by each factor

\begin{tabular}{|lcrccc|}
\hline Source & $\begin{array}{c}\text { Sum of } \\
\text { squares }\end{array}$ & df & $\begin{array}{c}\text { Mean } \\
\text { square }\end{array}$ & $\begin{array}{c}\text { Variance } \\
\text { component }\end{array}$ & $\begin{array}{c}\text { Contribution } \\
(\%)\end{array}$ \\
\hline $\begin{array}{l}\text { Total } \\
\text { (corrected) }\end{array}$ & 7.89 & 479 & & & \\
Group & 0.048 & 1 & 0.048 & 0.0 & 0.00 \\
Reef & 0.420 & 8 & 0.052 & 0.0 & 0.00 \\
Zone & 0.843 & 17 & 0.050 & 0.002 & 12.64 \\
Error & 6.580 & 453 & 0.015 & 0.015 & 87.36 \\
\hline
\end{tabular}

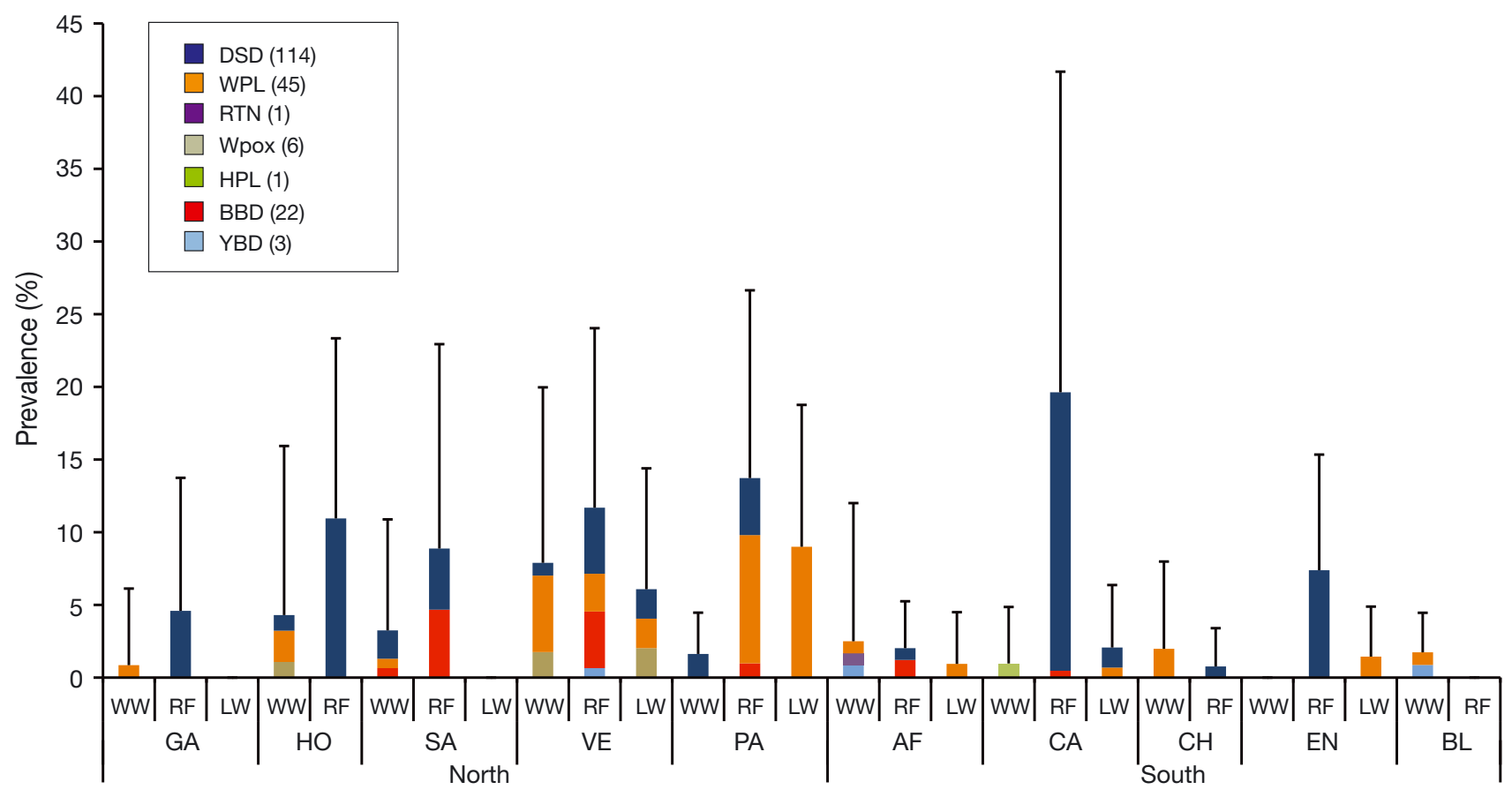

Group, reef, zone

Fig. 2. Prevalence (\%) of coral disease in the Veracruz Reef System by Group, Reef and Zone surveyed. Error bars are standard deviation of the mean. Reef acronyms as in Fig. 1. Reef Zone acronyms: WW = windward side, RF $=$ reef flat, $L W=$ leeward side. Disease acronyms: DSD = dark spots disease, WPL = white plague, RTN = rapid tissue necrosis, Wpox $=$ white pox disease, HPL $=$ hyperplasia, $\mathrm{BBD}=$ black band disease, $\mathrm{YBD}=$ yellow band disease. The number of coral colonies (192 in total) affected by each disease is indicated in parentheses in the key 
Table 3. Number of transects and stony corals (in parentheses) surveyed per Group, Reef and Zone to evaluate diseases in the Veracruz Reef System, and prevalence of disease on each reef. See Fig. 1 for reef acronyms. ND = no data; NLee $=$ Fringing reef, i.e. without leeward side. Reefs not sharing the same superscript letter have significantly different disease prevalence (Tukey's HSD test)

\begin{tabular}{|c|c|c|c|c|c|}
\hline Reef & Windward side & $\begin{array}{c}\text { Zone } \\
\text { Reef flat }\end{array}$ & Leeward side & Total & $\begin{array}{c}\text { Disease } \\
\text { prevalence (\%) }\end{array}$ \\
\hline \multicolumn{6}{|c|}{ North group } \\
\hline GA & $26(117)$ & 20 (196) & $16(138)$ & $62(451)$ & $2.2^{\mathrm{a}}$ \\
\hline VE & $15(114)$ & $20(154)$ & $10(148)$ & 45 (416) & $8.7^{\mathrm{b}}$ \\
\hline $\mathrm{HO}$ & $22(93)$ & $14(137)$ & NLee & $36(230)$ & $8.3^{\mathrm{b}}$ \\
\hline PA & $9(123)$ & 15 (102) & 8 (100) & 32 (325) & $7.7^{\mathrm{b}}$ \\
\hline SA & $16(154)$ & $22(214)$ & 10 (109) & $48(477)$ & $5.0^{\mathrm{c}}$ \\
\hline \multicolumn{6}{|c|}{ South group } \\
\hline $\mathrm{AF}$ & $38(120)$ & $10(247)$ & 17 (212) & 65 (579) & $1.7^{\mathrm{a}}$ \\
\hline EN & 27 (114) & $18(176)$ & $11(208)$ & 56 (498) & $3.2^{\mathrm{a}, \mathrm{c}}$ \\
\hline BL & 7 (115) & $17(73)$ & ND & 24 (188) & $1.1^{\mathrm{a}}$ \\
\hline $\mathrm{CA}$ & 26 (103) & 49 (214) & 17 (145) & 92 (462) & $9.9^{\mathrm{b}}$ \\
\hline $\mathrm{CH}$ & 7 (101) & $13(261)$ & ND & $20(362)$ & $1.1^{\mathrm{a}}$ \\
\hline Total & $193(1154)$ & $198(1774)$ & 89 (1060) & $480(3988)$ & \\
\hline
\end{tabular}

$(0.1 \%)$, and YBD $(0.1 \%)$. DSD affected all genera and WPL was present in all genera except Stephanocoenia. RTN was present only in Montastraea and HPL only in Colpophyllia.

\section{DISCUSSION}

The results of the Variance Components Analysis (Table 2) mean that the distribution of diseases in the VRS is mainly explained at a lower scale than Reef zone; amongst the factors considered herein, Reef zone made the highest contribution to the geographic distribution of coral diseases. This indicates that the distribution of diseases is patchy in the VRS, as observed in other Caribbean reefs (e.g. Bruckner \& Bruckner 1997a,b, 2006, Weil et al. 2002, Bruno et al. 2003, 2007). Weil \&

highest contribution to disease prevalence (12.64\%). Prevalence by Group was significantly higher in the North group $(6.0 \%)$ than in the South group $(3.8 \%)(t-$ test for independent samples, $\mathrm{p}<0.0001, t=10.69)$. At the Reef level (Fig. 2), prevalence was significantly different between reefs (1-way ANOVA, $\mathrm{n}=10, \mathrm{p}<$ 0.0001, $F=45.7$; Table 3). Between Zones (Fig. 2) prevalence was significantly different (1-way ANOVA, $\mathrm{n}=3, \mathrm{p}<0.0001, F=131.3)$, and a Tukey's HSD test showed that prevalence was significantly higher on the reef flats $(7.8 \%)$ than in the windward and leeward zones $(2.5 \%$ in both cases).

Seven diseases were observed on corals in $85.2 \%$ of the 27 reef zones that were evaluated. Of the 3988 corals surveyed, $192(4.8 \%)$ presented signs of disease (Fig. 2). DSD had the highest prevalence (2.9\%) and widest distribution, at both the community and the genus level (Figs. 2 \& 3), followed by WPL (1.1\%), and BBD $(0.6 \%)$. The lowest prevalence was for HPL and RTN (0.03\% in both cases). HPL was found only in the windward zone of Cabezo Reef; RTN was found only in the windward zone of Anegada de Afuera Reef.

Prevalence of disease as a function of genus is presented in Fig. 3. Six of the 16 registered genera were affected by a disease (Table 1): Colpophyllia, Diploria, Montastraea, Porites, Siderastrea and Stephanocoenia. Disease prevalence in Siderastrea was significantly higher $(9.1 \%)$ than in the other 5 genera (1-way ANOVA, $\mathrm{n}=6, \mathrm{p}<0.0001, F=94.4)$; this genus was affected by 3 diseases: DSD (6.5\%), WPL (1.5\%) and BBD $(1.1 \%)$. Diploria showed signs of DSD $(1.4 \%)$, $\operatorname{BBD}(0.9 \%)$, WPL $(0.2 \%)$ and YBD $(0.2 \%)$. Montastraea was affected by WPL $(0.9 \%)$, Wpox $(0.8 \%)$, RTN
Croquer (2009) consider that the patchy distribution of diseases in several reefs of the Caribbean must be linked to variations in the abundance and spatial distri-

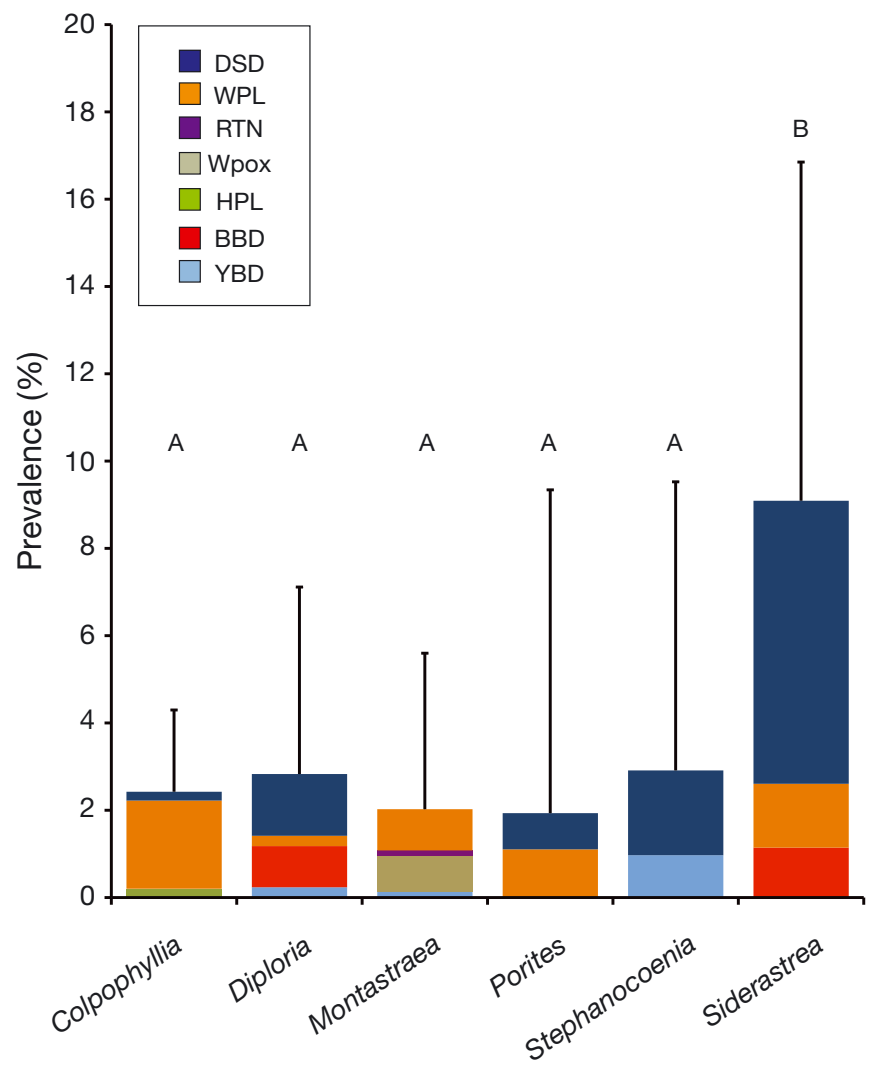

Fig. 3. Prevalence (\%) of disease for each coral genus affected in the Veracruz Reef System. Levels not connected by the same letter are significantly different. Disease acronyms as in Fig. 2 
bution of corals, environmental conditions and the availability of pathogens. With our present knowledge of coral communities in the VRS, the patchy distribution of diseases observed here cannot be explained; however, it is likely that environmental conditions are influential. Low water movement, low wave energy, and shallow depths (0.5 to $2 \mathrm{~m}$ ) characterize the reef flat zones (Horta-Puga 2003). Thus, while turbid waters characterize the entire VRS, the reef flat zones are exposed to higher light intensity and higher water temperatures than the windward and leeward sides (Chávez et al. 2007). Such conditions favor the presence and availability of pathogens and coral diseases (Alker et al. 2001, Kuta \& Richardson 2002), and might explain the higher incidence of disease in the reef flat zones in the VRS.

Reefs are better developed in the South group, with larger reefs extending farther offshore, than in the North group, with smaller reefs nearshore (see Carricart-Ganivet \& Horta-Puga 1993, Tunnell 2007). Nonetheless, within the VRS, there are more terrigenous sediments at the reefs in the South group than at the reefs in the North group and, due to the prevailing water circulation, the North group is less influenced by inflow from the Jamapa River (Carriquiry \& HortaPuga 2010). These conditions favor higher light intensity in the reefs from the North group than in those of the South group, favoring disease prevalence in the former group.

In line with results presented here for the VRS, Weil (2004) and Calnan et al. (2008) reported that DSD is among the most prevalent and widely distributed coral diseases in the Caribbean. Weil \& Croquer (2009) noted that the occurrence of some diseases seems to be correlated with the distribution and abundances of susceptible coral species in the Caribbean Sea. Siderastrea, Colpophyllia, Montastraea and Diploria are the most abundant coral genera in the VRS (HortaPuga 2003), and all 6 genera reported here as having diseased colonies have been identified as susceptible to the same diseases in other reef locations in the Caribbean (Ward et al. 2006, Weil \& Croquer 2009).

Weil \& Croquer (2009), working in reefs of the Caribbean, also found diseases to be widely distributed but with low values for total prevalence. These authors suggested that values of total disease prevalence between $1 \%$ and $6 \%$ could be considered as normal at the community level in the Caribbean reefs. Thus, the total coral disease prevalence of $4.8 \%$ found in the VRS is within the normal range for the Caribbean. Nonetheless, considering that the VRS is affected by severe environmental problems, including factors that increase disease prevalence (i.e. increased SST and low water quality), a higher disease prevalence than that obtained in this study was expected.
The lower than expected disease prevalence in the VRS could be explained in 2 ways: (1) Coral reefs of the VRS develop in a turbid (i.e. decreased light) environment generated by the outflow of the Jamapa River (Morelock \& Koenig 1967, Tunnell 1988, CarricartGanivet \& Merino 2001, Carriquiry \& Horta-Puga 2010). Muller \& van Woesik (2009) suggested that reduced levels of irradiance decrease the rate of coral disease progression, by stressing the pathogenic microflora and reducing their virulence under low light conditions. (2) Miller et al. (2009) suggested that, although most coral species in the Caribbean can recover from massive bleaching events, during the recovery process they are likely to be more susceptible to diseases for several months. To our knowledge, there has not been a massive bleaching event in the VRS. Bleaching events occur when a combination of elevated temperature and irradiance is present (Brown 1997). Thus, even though environmental conditions that promote diseases, such as high nutrient concentrations and increased SST, are present in the VRS, the turbid waters may inhibit coral diseases by decreasing irradiance on corals, reducing the virulence of pathogenic microflora, and/or preventing bleaching events.

Acknowledgements. The comments of A.T. Banaszak and 2 anonymous reviewers notably improved the manuscript. We thank J.D. Carriquiry, J. Villaescusa (IIO, UABC), J. TelloMusi, M. Ávila-Romero, N. Colín-García, A. Morales-Díaz, J. Nuñez-Rico and A.I. Cruz-Ortega (FESI, UNAM) for their assistance with fieldwork. Special thanks to the staff of the 'Parque Nacional Sistema Arrecifal Veracruzano' for the facilities provided during the fieldwork. This research was supported by a grant from CONABIO (project DM005) to G.H.P.

\section{LITERATURE CITED}

Alker AP, Smith GW, Kim K (2001) Characterization of Aspergillus sydowii (Thom et Church), a fungal pathogen of Caribbean sea fan corals. Hydrobiologia 460:105-111

- Aronson RB, Precht WF, Toscano MA, Koltes KH (2002) The 1998 bleaching event and its aftermath on a coral reef in Belize. Mar Biol 141:435-447

Baker DM, MacAvoy SE, Kim K (2007) Relationship between water quality, $\delta^{15} \mathrm{~N}$, and aspergillosis of Caribbean sea fan corals. Mar Ecol Prog Ser 343:123-130

Ballantine DL, Appeldoorn RS, Yoshioka P, Weil E and others (2008) Biology and ecology of Puerto Rican coral reefs. In: Riegl MB, Dodge RE (eds) Coral reefs of the USA. Springer, Dortrecht, p 375-406

Brandt ME, McManus JW (2009) Disease incidence is related to bleaching extent in reef-building corals. Ecology 90: 2859-2867

Brown BE (1997) Coral bleaching: causes and consequences. Coral Reefs 16:S129-S138

Bruckner AW, Bruckner RJ (1997a) Spread of a black-band disease epizootic through the coral reef system in St. Ann's Bay, Jamaica. Bull Mar Sci 61:919-928 
Bruckner AW, Bruckner RJ (1997b) Outbreak of coral disease in Puerto Rico. Coral Reefs 16:260

Bruckner AW, Bruckner RJ (1998a) Disease and predation on scleractinian corals. Disease identification card, National Oceanic and Atmospheric Administration (NOAA), US Department of Commerce, Washington, DC

Bruckner AW, Bruckner RJ (1998b) Western Atlantic coral disease and predation: star coral (Montastraea annularis, $M$. faveolata, $M$. franksii). Disease identification card, National Oceanic and Atmospheric Administration (NOAA), US Department of Commerce, Washington, DC

Bruckner AW, Bruckner RJ (1998c) Disease, predation and tissue anomalies affecting stony and soft coral. Disease identification card, National Oceanic and Atmospheric Administration (NOAA), US Department of Commerce, Washington, DC

Bruckner AW, Bruckner RJ (1998d) Disease and predation: staghorn and elkhorn coral (Acropora cervicornis and Acropora palmata). Disease identification card, National Oceanic and Atmospheric Administration (NOAA), US Department of Commerce, Washington, DC

Bruckner AW, Bruckner RJ (2006) Consequences of yellow band disease (YBD) on Montastraea annularis (species complex) populations on remote reefs off Mona Island, Puerto Rico. Dis Aquat Org 69:67-73

Bruno JF, Petes LE, Harvell CD, Hettinger A (2003) Nutrient enrichment can increase the severity of coral diseases. Ecol Lett 6:1056-1061

Bruno JF, Selig ER, Casey KS, Page CA and others (2007) Thermal stress and coral cover as drivers of coral disease outbreaks. PLoS Biol 5:e124

Calnan JM, Smith TB, Nemeth RS, Kadison E, Blondeau J (2008) Coral disease prevalence and host susceptibility on mid-depth and deep reefs in the United States Virgin Islands. Rev Biol Trop 56:223-234

Carricart-Ganivet JP, Horta-Puga G (1993) Arrecifes de coral en México. In: Salazar-Vallejo SI, González NE (eds) Biodiversidad marina y costera de México. CONABIO y CIQRO, México, p 80-90

Carricart-Ganivet JP, Merino M (2001) Growth responses of the reef-building coral Montastraea annularis along a gradient of continental influence in the southern Gulf of Mexico. Bull Mar Sci 68:133-146

Carriquiry JD, Horta-Puga G (2010) The Ba/Ca record of corals from the Southern Gulf of Mexico: contributions from land-use changes, fluvial discharge and oil-drilling muds. Mar Pollut Bull 60:1625-1630

> Cervino J, Goreau TJ, Nagelkerken I, Smith GW, Hayes R (2001) Yellow band and dark spot syndromes in Caribbean corals: distribution, rate of spread, cytology, and effects on abundance and division rate of zooxanthellae. Hydrobiologia 460:53-63

Cervino JM, Hayes R, Polson SW, Polson SC, Goreau TJ, Martinez RJ, Smith GW (2004) Relationship of Vibrio species infection and elevated temperatures to yellow blotch/ band disease in Caribbean corals. Appl Environ Microbiol 70:6855-6864

Chávez EA, Tunnell JW, Withers K (2007) Reef zonation and ecology: Veracruz Shelf and Campeche Bank. In: Tunnell JW, Chávez EA, Withers K (eds) Coral reefs of the Southern Gulf of Mexico. Texas A\&M University Press, College Station, TX, p 41-67

> Cruz-Piñón G, Carricart-Ganivet JP, Espinoza-Avalos J (2003) Monthly skeletal extension rates of the hermatypic corals Montastraea annularis and Montastraea faveolata: biological and environmental controls. Mar Biol 143:491-500
Garzón-Ferreira J, Gil-Agudelo DL, Barrios LM, Zea S (2001) Stony coral diseases observed in southwestern Caribbean reefs. Hydrobiologia 460:65-69

Harvell D, Aronson RB, Baron N, Connell J and others (2004) The rising tide of ocean diseases: unsolved problems and research priorities. Front Ecol Environ 2:375-382

Harvell D, Jordán-Dahlgren E, Merkel SM, Rosenberg E and others (2007) Coral disease, environmental drivers, and the balance between coral and microbial associates. Oceanography 20:172-195

Horta-Puga G (2003) Condition of selected reef sites in the Veracruz Reef System (stony corals and algae). Atoll Res Bull 496:360-369

Horta-Puga G (2007) Environmental impacts. In: Tunnell JW, Chávez EA, Withers K (eds) Coral reefs of the Southern Gulf of Mexico. Texas A\&M University Press, College Station, TX, p 126-141

Horta-Puga G, Carricart-Ganivet JP (1990) Stylaster roseus (Pallas, 1766): first record of a Stylasterid (Cnidaria: Hydrozoa) in the Gulf of Mexico. Bull Mar Sci 47:575-576

Humann P (1998) Reef coral identification, Florida, Caribbean, Bahamas. New World Pub, Jacksonville, FL

IPCC (Intergovernmental Panel on Climate Change) (2007) Climate change 2007: synthesis report. Contribution of working groups I, II and III to the fourth assessment report of the Intergovernmental Panel on Climate Change [Core Writing Team: Pachauri RK, Reisinger A (eds)]. IPCC, Geneva

Kim K, Harvell C (2002) Aspergillosis of sea fan corals: disease dynamics in the Florida Keys, USA. In: Porter J, Porter K (eds) The Everglades, Florida Bay, and coral reefs of the Florida Keys: an ecosystem handbook. CRC Press, Boca Raton, FL, p 813-824

Kuta KG, Richardson LL (2002) Ecological aspects of black band disease of corals: relationships between disease incidence and environmental factors. Coral Reefs 21:393-398

Lang J, Alcolado P, Carricart-Ganivet JP, Chiappone M and others (1998) Status of coral reefs in the northern areas of the wider Caribbean. In: Wilkinson C (ed) Status of coral reefs of the world: 1998. Australian Institute of Marine Science, Townsville, p 123-134

Luna GM, Biavasco F, Danovaro R (2007) Bacteria associated with the rapid tissue necrosis of stony corals. Environ Microbiol 9:1851-1857

Miller J, Muller E, Rogers C, Waara R and others (2009) Coral disease following massive bleaching in 2005 causes $60 \%$ decline in coral cover on reefs in the US Virgin Islands. Coral Reefs 28:925-937

Morelock J, Koenig KJ (1967) Terrigenous sedimentation in a shallow water coral reef environment. J Sed Petrol 37 : 1001-1005

Muller EM, van Woesik R (2009) Shading reduces coraldisease progression. Coral Reefs 28:757-760

Rayner NA, Parker DE, Horton EB, Folland CK and others (2003) Global analyses of sea surface temperature, sea ice, and night marine air temperature since the late nineteenth century. J Geophys Res 108:4407 doi: 10.1029/ 2002JD002670

Richardson LL, Goldberg WM, Kuta KG, Aronson RB and others (1998) Florida's mystery coral-killer identified. Nature 392:557-558

Rodríguez-Martínez RE, Banaszak AT, Jordán-Dahlgren E (2001) Necrotic patches affect Acropora palmata (Scleractinia: Acroporidea) in the Mexican Caribbean. Dis Aquat Org 47:229-234

Tunnell JW (1988) Regional comparison of southwestern Gulf of Mexico to Caribbean Sea coral reefs. Proc 6th Int Coral Reef Symp 3:303-308 
Tunnell JW (1992) Natural versus human impacts to Southern Gulf of Mexico coral reefs resources. Proc 7th Int Coral Reef Symp 1:300-306

Tunnell JW (2007) Reef distribution. In: Tunnell JW, Chávez EA, Withers K (eds) Coral reefs of the Southern Gulf of Mexico. Texas A\&M University Press, College Station, TX, p 14-22

Voss JD, Richardson LL (2006) Nutrient enrichment enhances black band disease progression in corals. Coral Reefs 25: 569-576

Ward JR, Lafferty KD (2004) The elusive baseline of marine disease: Are diseases in ocean ecosystems increasing? PLoS Biol 2(4):e120

Ward JR, Rypien KL, Bruno JF, Harvell CD and others (2006) Coral diversity and disease in Mexico. Dis Aquat Org 69: 23-31

Weil E (2004) Coral reef diseases in the wider Caribbean. In:

Editorial responsibility: Garriet Smith,

Aiken, South Carolina, USA
Rosenberg EH, Loya Y (eds) Coral health and disease. Springer-Verlag, Berlin, p 35-68

Weil E, Croquer A (2009) Spatial variability in distribution and prevalence of Caribbean scleractinian coral and octocoral diseases. I. Community-level analysis. Dis Aquat Org 83:195-208

Weil E, Urreiztieta I, Garzon-Ferreira J (2002) Geographic variability in the incidence of coral and octocoral diseases in the wider Caribbean. Proc 9th Int Coral Reef Symp 2: 1231-1237

Weil E, Smith G, Gil-Agudelo DL (2006) Status and progress in coral reef disease research. Dis Aquat Org 69:1-7

Willis BL, Page CA, Dinsdale EA (2004) Coral disease on the Great Barrier Reef. In: Rosenberg EH, Loya Y (eds) Coral health and disease. Springer-Verlag, Berlin, p 69-104

$>$ Work TM, Rameyer RA (2005) Characterizing lesions in corals from American Samoa. Coral Reefs 24:384-390

Submitted: October 18, 2010; Accepted: March 15, 2011

Proofs received from author(s): June 13, 2011 